\begin{tabular}{|l|l|l|}
\hline Received : 20/04/2021 & Accepted: 20/06/2021 & Published : 30/06/2021 \\
\hline
\end{tabular}

\title{
ANALISIS ERGONOMI BEBAN KERJA TERHADAP KELELAHAN KERJA PADA PEKERJA MANUAL BATU BATA DENGAN REGRESI LINIER BERGANDA BERBASIS WEB
}

\author{
Junaini ${ }^{1)^{*}}$, Yano Hurung Anoi ${ }^{2}$, Yunanri. W' \\ 1, 2 Program Studi Teknik Mesin Sekolah Tinggi Teknologi Industri (STTI) Bontang \\ ${ }^{3}$ Program Studi Teknik Informatika Universitas Teknologi Sumbawa NTB \\ ${ }^{1,2} \mathrm{Jl}$ Brigjend Katamso Nomor 40, Bontang, 75313 \\ ${ }^{3} J l$. Raya Olat Maras, Batu Alang, Moyo Hulu - Kabupaten Sumbawa - NTB \\ *Email:jhunaini99@yahoo.co.id
}

\begin{abstract}
Small industry has a big role in encouraging development in areas, especially rural areas, which cannot be separated from national development in accordance with regional autonomy and regional aspirations. One of the small industries to fulfill development is the brick-making industry manually because it still uses a simple process in its production. Manual brick making cannot be separated from the risks that will arise for workers, one of the risks is fatigue due to the workload carried out in the process of making bricks repeatedly, the workload can be in the form of physical loads or mental loads. Fatigue from work will reduce performance and increase the rate of work errors. Increasing work errors will provide opportunities for work accidents. From this it is necessary to measure workload on work fatigue from the results of the ergonomic analysis of brickwork manual workers with Linear Regression with web-based programming. Each worker will be recorded based on the category Initial Pulse, Work Rate, Body Weight, Blood Pressure, Height, Age, as well as several questions to workers needed to measure the workload against work fatigue. Questions about Activity Weakness and Physical Fatigue in a span of days (Very Often, Often, Sometimes, Never; to each worker. The conclusion from the results of the workload analysis has an influence on fatigue of work in making bricks manually, namely Normal or Not Fatigue 6 workers, and Needs Improvement 9 workers with the percentage classification of Cardiovascular Load (CVL) is $40 \%$ and $60 \%$.
\end{abstract}

Keywords: Workload, fatigue, Linear Regression

\begin{abstract}
Abstrak
Industri kecil memiliki peranan yang besar dalam mendorong pembangunan di daerah khususnya pedesaan yang tidak terlepas dari pembangunan nasional disesuaikan dengan otensi daerah dan aspirasi daerah. Salah satu industri kecil untuk memenuhi pembangunan adalah industri pembuatan batu bata secara manual karena masih menggunakan proses sederhana dalam produksinya. Pembuatan batu bata secara manual tidak lepas dari risiko-risiko yang akan timbul bagi pekerja, salah satu risiko adalah kelelahan akibat beban kerja yang dilakukan dalam proses pembuatan batu bata secara berulang-ulang, beban kerja tersebut dapat berupa beban fisik maupun beban mental. Kelelahan kerja akan menurunkan kinerja dan menambah tingkat kesalahan kerja. Meningkatnya kesalahan kerja akan memberikan peluang terjadinya kecelakaan kerja. Dari hal tersebut perlu mengukur beban kerja terhadap kelelahan kerja dari hasil analisis ergonomic pekerja manual batu bata dengan Regresi Linier dengan pemrograman berbasis web. Setiap pekerja akan didata berdasarkan kategori Denyut Nadi Awal, Denyut Nadi Kerja, Berat Badan, Tekanan Darah, Tinggi Badan, Umur, serta beberapa pertanyaan kepada pekerja yang dibutuhkan untuk mengukur beban kerja terhadap kelelahan kerja. Pertanyaan tentang Pelemahan Kegiatan dan Kelelahan Fisis dalam rentang hari (Sangat Sering, Sering, Kadang-Kadang, Tidak Pernah; kepada setiap pekerja. Kesimpulan dari hasil analisis beban kerja mempunyai pengaruh terhadap kelelahan kerja pembuatan batu bata secara manual yaitu Normal atau Tidak Kelelahan 6 pekerja, dan Perlu Perbaikan 9 pekerja dengan klasifikasi persentase Beban Kardiovaskular (Cardiovascular Load/CVL) adalah 40\% dan 60\%.
\end{abstract}

Kata kunci: Beban kerja, kelelahan, Regresi Linier.

\section{Pendahuluan}

Setiap upaya pembangunan ekonomi daerah bertujuan meningkatkan jenis dan peluang kerja. Pembangunan ekonomi daerah di era otonomi menghadapi berbagai tantangan baik internal maupun eksternal, seperti masalah kesenjangan dan iklim globalisasi, yang akhirnya 
menuntut tiap-tiap daerah untuk mampu bersaing di dalam dan di luar negeri, dan tidak terlepas pula adanya industri kecil yang berperan dalam pembangunan ekonomi daerah.

Salah satu industri kecil untuk memenuhi pembangunan adalah industri pembuatan batu bata secara manual karena masih menggunakan proses sederhana dalam produksinya. Pembuatan batu bata secara manual tidak lepas dari risiko-risiko yang akan timbul bagi pekerja, salah satu risiko adalah kelelahan akibat beban kerja yang dilakukan dalam proses pembuatan batu bata secara berulang-ulang, beban kerja tersebut dapat berupa beban fisik maupun beban mental. Pada dasarnya semua jenis dan beban kerja akan menghasilkan kelelahan kerja. Kelelahan kerja akan menurunkan kinerja dan menambah tingkat kesalahan kerja. Meningkatnya kesalahan kerja akan memberikan peluang terjadinya kecelakaan kerja. Kelelahan kerja terhadap pekerja menunjukkan keadaan yang berbeda-beda, tetapi semuanya berakibat kepada pengurangan kapasitas kerja dan ketahanan tubuh pekerja (Tarwaka, 2010).

Berdasarkan permasalahan tersebut dan perlu dilakukan analisis ergonomi beban kerja terhadap kelelahan kerja pada pekerja manual batu bata dengan Regresi Linier Berganda menggunakan aplikasi berbasis web.

\section{Tinjauan Teori}

\subsection{Beban Kerja}

Beban Kerja Beban kerja adalah sekumpulan atau sejumlah kegiatan yang harus diselesaikan oleh suatu unit organisasi atau pemegang jabatan dalam jangka waktu tertentu Sunarso (2010). Permendagri No. 12/2008 menyatakan bahwa beban kerja adalah besaran pekerjaan yang harus dipikul oleh suatu jabatan/unit organisasi dan merupakan hasil kali antara volume kerja dan norma waktu. Jika kemampuan pekerja lebih tinggi daripada tuntutan pekerjaan,akan muncul perasaan bosan. Namun sebaliknya, jika kemampuan pekerja lebih rendah daripada tuntutan pekerjaan,maka akan muncul kelelahan yang lebih. Beban kerja yang dibebankan kepada karyawan dapat dikategorikan kedalam tiga kondisi, yaitu beban kerja yang sesuai standar, beban kerja yang terlalu tinggi (over capacity) dan beban kerja yang terlalu rendah (under capacity).

\subsection{Kelelahan Kerja}

Menurut Suma'mur (2010), Salah satu permasalah K3 (Kesehatan dan KeselamatanKerja) yang dapat menjadi pemicu terjadinya kecelakaan kerja adalah kelelahan. Kelelahan kerja merupakan suatu keadaan menurunnya efisiensi dan ketahanan seseorang dalam bekerja. Sedangkan Nurmianto, (2003), istilah kelelahan mengarah pada kondisi melemahnya tenaga kerja untuk melakukan suatu kegiatan, sehingga mengakibatkan terjadinya pengurangan kapasitas kerja dan ketahanan tubuh.

Pernyataan dari World Health Organization(WHO) meramalkan bahwa yang menjadi penyakit pembunuh nomor 2 setelah penyakit jantung adalah perasaan lelah yang berat.3Kementerian tenaga kerja Jepang melakukan penelitian terhadap 12 ribu perusahaan dan melibatkan sekitar 16 ribu orang tenaga kerja yang dipilih secara random, hasil dari penelitian tersebut menunjukkan bahwa $65 \%$ tenaga kerja mengeluhkan kelelahan fisik akibat kerja rutin, $28 \%$ mengeluhkan kelelahan mental dan sekitar $7 \%$ pekerja mengeluh stress berat dan merasa tersisihkan.

\subsection{Penelitian Terdahulu}

Penelitian terdahulu berjudul: Analisis Beban Kerja Terhadap Kelelahan Kerja Antara Shift Pagi Dan Shift Siang Pada Pekerja Di Bagian Operasional (Hidayah, Musyarofah, dan Widjasena, 2018). Penelitian ini menggunakan metode deskriptif analitik dengan pendekatan cross sectional. Sampel berjumlah 9 pekerja bagian operasional Depot Pengisian Pesawat Udara Ahmad Yani Semarang yang diambil dengan menggunakan teknik total sampling. Pengukuran kelelahan kerja menggunakan uji ketuk jari (finger taping test) pada aplikasi 
android, untuk pengukuran beban kerja fisik menggunakan uji denyut nadi dan pengukuran beban kerja mental menggunakan kuesioner NASA-TLX yang diambil pada saat bekerja.

Hasil: analisis dengan menggunakan uji Paired t-test menunjukkan bahwa 95\% terdapat perbedaan yang signifikan kelelahan kerja $(\mathrm{p}=0,027)$, beban kerja fisik $(\mathrm{p}=0,003)$, dan beban kerja mental $(\mathrm{p}=0,040)$ antara shift pagi dan shift siang pada pekerja bagian operasional. Pekerja disarankan untuk melakukan peregangan otot seperti menggerakkan kepala, tangan, dan kaki disela-sela pekerjaan ataupun saat istirahat, dengan tujuan supaya tubuh tidak terlalu lama dalam keadaan statis yang dapat mengakibatkan tenaga kerja menjadi cepat lelah.

Penelitian terdahulu lainnya dengan judul: Analisis Faktor Risiko Kelelahan Kerja Pada Karyawan Bagian Produksi PT. Arwana Anugrah Keramik, Tbk (Juliana, Camelia, dan Ramiwati, 2018). Penelitian ini menggunakan metode analitik dengan pendekatan cross sectional. Populasi dalam penelitian ini adalah seluruh karyawan yang ada di bagian produksi PT. Arwana Anugrah Keramik, Tbk yang berjumlah 168 orang. Teknik sampling yang digunakan yaitu propability sampling dengan teknik simple random sampling diperoleh sampel sebesar 75 orang. Pengumpulan data primer menggunakan kuesioner dan data sekunder (studi dokumentasi). Teknik pengolahan data menggunakan Teknik analisis data yaitu Chi-square. Berdasarkan hasil penelitian yang dilakukan diperoleh bahwa usia $(p$-value $=0,793)$ dan masa kerja ( $p$-value $=0,337)$ tidak memiliki hubungan yang signifikan dengan kelelahan kerja, sedangkan status anemia $(p$-value $=0,012)$, shift kerja $(p$-value $=0,021)$, kualitas tidur $(p$ value $=0,0001)$, beban kerja $(p$-value $=0,001)$, dan iklim kerja panas $(p$-value $=0,004)$ memiliki hubungan yang signifikan dengan kelelahan kerja.

Faktor yang berhubungan dengan kelelahan kerja pada karyawan bagian produksi PT. Arwana Anugrah Keramik, Tbk adalah status anemia, shift kerja, kualitas tidur, beban kerja, dan iklim kerja panas. Untuk mencegah kelelahan kerja, perusahaan PT. Arwana Anugrah Keramik, Tbk sebaiknya menyediakan alat angkut untuk meringankan beban kerja karyawan, menyediakan air minum pada jarak yang relative terjangkau, serta memperbolehkan karyawan untuk beristirahat sejenak (10-15 menit) setiap 1-2 jam kerja.

Dari dua penelitian terdahulu tersebut, peneliti diharapkan dapat menganalisis beban kerja terhadap kelelahan kerja dengan metode Regresi Linier Berganda yang menggunakan aplikasi berbasis web.

\section{Metode Penelitian}

\subsection{Metode Penelitian}

Penelitian ini menggunakan metode analisis ergonomi dengan tahapan pengolahan data, setelah penulis melakukan pengumpulan data maka dilanjutkan pengolahan data mengukur denyut nadi, mengukur berat badan, tekanan darah, dan mengukur tinggi badan untuk dikumpulkan dengan prakiraan data yang didapat minimal 15 pekerja manual bagian percetakan batu bata. Metode pengujian, setelah penulis melakukan pengolahan data, tahap selanjutnya melakukan pengujian terhadap sample data dari angka denyut nadi, berat badan, tekanan darah, dan tinggi badan. Metode pengujian yang dilakukan adalah Uji Normalitas, Uji Linearitas dan Uji Regresi Linier.

\subsection{Gambaran Umum}

Pelaksanaan penelitian di Desa Pal Besi, Kelurahan Loa Bakung, Samarinda yang memiliki usaha pembuatan batu bata yaitu dua tempat usaha dengan objek penelitian adalah pekerja manual batu bata khususnya bagian pencetakan.

Pembuatan batu bata memerlukan tanah liat yang sesuai spesifikasi batu bata yang menjadi prasyarat. Lokasi yang akan digunakan dalam pembuatan batu bata ini haruslah memiliki luas tanah yang cukup untuk menampung segala proses dan juga peralatan yang digunakan dalam 
proses pembuatan batu bata. Beberapa proses dari pembuatan batu bata yang membutuhkan ruang cukup antara lain adalah:

a.Lokasi pengolahan tanah atau lahan tambang tanah liat merah

b.Tempat pencetakan batu bata merah

c. Tempat untuk membakar batu bata merah

d.Tempat penyimpanan batu bata yang sudah jadi.

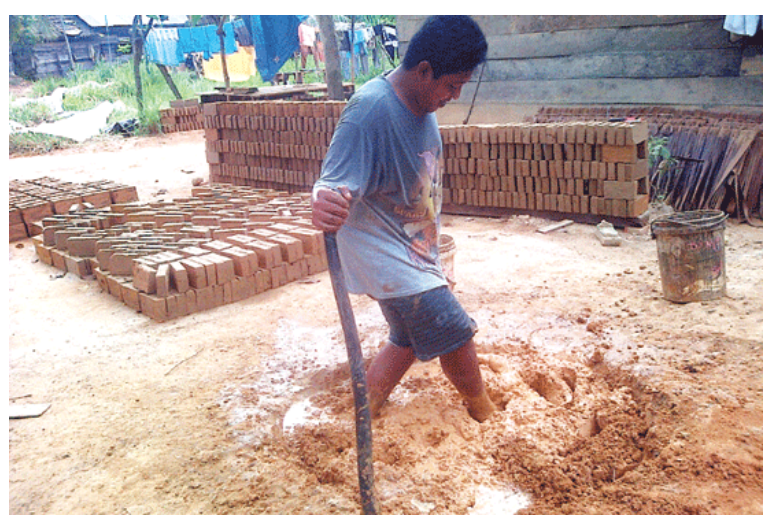

Gambar 1. Proses Penghalusan Tanah Liat Secara Manual

Hasil tanah yang telah dihaluskan didiamkan satu malam untuk menghilangkan kadar air yang terlalu banyak. Setelah dirasa cukup untuk kadar air ditanah liat tersebut selanjutnya dapat dilakukan proses pencetakan tanah liat dengan menggunakan cetakan yang berisi satu atau tiga cetakan. Proses selanjutnya cetakan yang berisis tanah liat tersebut dibawa ketempat proses penjemuran batu bata (brak) dan tanah liat tersebut dikeluarkan dari cetakan,

Proses pencetakan tersebut dilakukan secara berulang - ulang sampai tempat penjemuran batu bata penuh, jumlah hasil batu bata yang telah dicetak dalam satu hari itu tergantung dari luas tempat penjemuran batu bata dapat berkisar antara $500-1000$ batu bata dalam satu hari. Kemudian proses penjemuran tanah liat yang telah dicetak di diamkan selama satu hari, selanjutnya hasil cetakan tersebut disusun secara rapi.

Setelah tanah liat yang dicetak tersebut dirasa sudah mencukupi Proses selanjutnya yaitu proses penyusunan hasil cetakan untuk pembakaran, pada proses pembakaran hasil cetakan memerlukan waktu selama satu hari satu malam (24 jam) dan bahan pembakaran menggunakan kayu bakar.

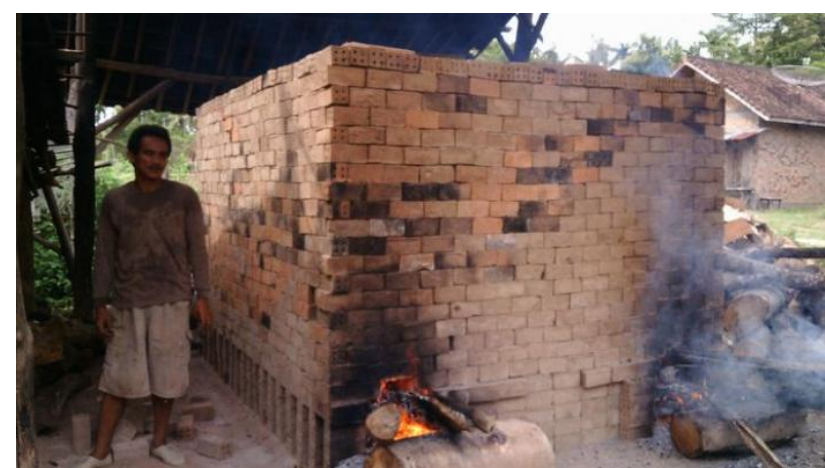

Gambar 2. Proses Pembakaran Batu Bata

\section{Hasil Penelitian}

\subsection{Data Lapangan}

Observasi langsung di tempat produksi batu bata Desa Pal Besi, Kelurahan Loa Bakung, Samarinda. Data-data yang dibutuhkan untuk analisis ergonomi dan dengan mewawancarai 
selanjutnya diadakan analisis, maka dapat dikategorikan hasil data lapangan adalah denyut nadi, berat badan, tekanan darah, dan tinggi badan dari masing-masing pekerja manual batu bata.

\subsubsection{Data Ergonomi}

Analisis Ergonomi dalam tahap analisis ergonomi dengan tahapan selanjutnya adalah mengukur pekerja manual batu bata dengan hasil data lapangan sebagai berikut:

Table 1. Data Pekerja Batu Bata

\begin{tabular}{|c|c|c|c|c|c|c|c|}
\hline \multirow{2}{*}{ Pekerja } & \multirow{2}{*}{$\begin{array}{c}\text { Denyut Nadi } \\
\text { Awal } \\
\text { Denyut/mnt }\end{array}$} & \multirow{2}{*}{$\begin{array}{c}\text { Denyut Nadi } \\
\text { Kerja }\end{array}$} & \multirow{2}{*}{$\begin{array}{c}\text { Berat } \\
\text { Badan (kg) }\end{array}$} & \multicolumn{2}{|c|}{ Tekanan Darah } & \multirow{2}{*}{$\begin{array}{l}\text { Tinggi } \\
\text { Badan }\end{array}$} & \multirow{2}{*}{$\begin{array}{l}\text { Umur } \\
\text { Tahun }\end{array}$} \\
\hline & & & & Sistolik & Diastolik & & \\
\hline 1 & 66 & 97 & 50 & 123 & 80 & (m) & 22 \\
\hline 2 & 72 & 132 & 48 & 155 & 70 & 1.65 & 36 \\
\hline 3 & 72 & 130 & 54 & 113 & 73 & 1.59 & 38 \\
\hline 4 & 78 & 110 & 49 & 150 & 97 & 1.70 & 36 \\
\hline 5 & 75 & 108 & 48 & 115 & 72 & 1.63 & 28 \\
\hline 6 & 74 & 115 & 48 & 115 & 75 & 1.63 & 28 \\
\hline 7 & 78 & 100 & 52 & 109 & 67 & 1.62 & 29 \\
\hline 8 & 78 & 125 & 46 & 116 & 69 & 1.62 & 26 \\
\hline 9 & 78 & 95 & 51 & 110 & 65 & 1.59 & 51 \\
\hline 10 & 75 & 131 & 57 & 123 & 73 & 1.62 & 21 \\
\hline 11 & 61 & 108 & 42 & 112 & 63 & 1.48 & 49 \\
\hline 12 & 69 & 126 & 48 & 105 & 60 & 1.61 & 27 \\
\hline 13 & 72 & 130 & 59 & 111 & 60 & 1.65 & 46 \\
\hline 14 & 66 & 98 & 49 & 140 & 86 & 1.64 & 21 \\
\hline 15 & 75 & 120 & 50 & 119 & 80 & 1.62 & 38 \\
\hline
\end{tabular}

\subsubsection{Persentase Pelemahan Kegiatan Dan Kelelahan Fisik}

Penentuan angka skor dari data pekerja pembuatan batu bata secara manual di Desa Pal Besi, Loa Bakung, Samarinda, sebanyak 15 perhitungan ini menggunakan rumus persamaan untuk menghitung Pelemahan Kegiatan dan Kekelahan Fisik dengan persentase.

Table 2. Data Jawaban Pelemahan Kegiatan Dalam Rentang Hari

\begin{tabular}{|c|c|c|c|c|}
\hline \multirow{2}{*}{ Data Kerja Ke } & \multicolumn{4}{|c|}{ Jumlah Jawaban Rentang Hari (10 Pekerja) } \\
\cline { 2 - 5 } & Sangat Sering & Sering & Kadang-kadang & Tidak Pernah \\
\hline 1 & 3 & 5 & 2 & 0 \\
\hline & $30 \%$ & $50 \%$ & $20 \%$ & $0 \%$ \\
\hline 2 & 3 & 5 & 1 & 1 \\
\hline 3 & $30 \%$ & $50 \%$ & $10 \%$ & $10 \%$ \\
\hline & 3 & 7 & 0 & 0 \\
\hline 4 & $30 \%$ & $70 \%$ & $0 \%$ & $0 \%$ \\
\hline
\end{tabular}




\begin{tabular}{|c|c|c|c|c|}
\hline & $10 \%$ & $30 \%$ & $50 \%$ & $10 \%$ \\
\hline 5 & $\mathbf{0}$ & 1 & 6 & 3 \\
\hline & $0 \%$ & $10 \%$ & $60 \%$ & $30 \%$ \\
\hline 6 & 0 & 5 & 2 & 3 \\
\hline & $0 \%$ & $50 \%$ & $20 \%$ & $30 \%$ \\
\hline 7 & $\mathbf{0}$ & 1 & 4 & 5 \\
\hline 8 & $0 \%$ & $10 \%$ & $40 \%$ & $50 \%$ \\
\hline & $\mathbf{0}$ & 1 & 2 & 7 \\
\hline 9 & $0 \%$ & $10 \%$ & $20 \%$ & $70 \%$ \\
\hline & $\mathbf{0}$ & 1 & 8 & 1 \\
\hline 10 & $0 \%$ & $10 \%$ & $80 \%$ & $10 \%$ \\
\hline & 3 & 5 & 1 & 1 \\
\hline & $30 \%$ & $50 \%$ & $10 \%$ & $10 \%$ \\
\hline
\end{tabular}

Tabel 3. Data Jawaban Kelelahan Fisik Dalam Rentang Hari

\begin{tabular}{|c|c|c|c|c|}
\hline \multirow{2}{*}{ Data Kerja Ke } & \multicolumn{4}{|c|}{ Jumlah Jawaban Rentang Hari (10 Pekerja) } \\
\hline & Sangat Sering & Sering & Kadang-kadang & Tidak Pernah \\
\hline \multirow[t]{2}{*}{1} & 1 & 2 & 4 & 3 \\
\hline & $10 \%$ & $20 \%$ & $40 \%$ & $30 \%$ \\
\hline \multirow[t]{2}{*}{2} & 2 & 5 & 2 & 1 \\
\hline & $20 \%$ & $50 \%$ & $20 \%$ & $10 \%$ \\
\hline \multirow[t]{2}{*}{3} & 3 & 5 & 1 & 1 \\
\hline & $30 \%$ & $50 \%$ & $10 \%$ & $10 \%$ \\
\hline \multirow[t]{2}{*}{4} & $\mathbf{0}$ & 1 & 3 & 6 \\
\hline & $0 \%$ & $10 \%$ & $30 \%$ & $60 \%$ \\
\hline \multirow[t]{2}{*}{5} & 1 & 2 & 4 & 3 \\
\hline & $10 \%$ & $20 \%$ & $40 \%$ & $30 \%$ \\
\hline \multirow[t]{2}{*}{6} & 0 & 1 & 2 & 7 \\
\hline & $0 \%$ & $10 \%$ & $20 \%$ & $70 \%$ \\
\hline \multirow[t]{2}{*}{7} & $\mathbf{0}$ & 2 & 7 & 1 \\
\hline & $0 \%$ & $20 \%$ & $70 \%$ & $10 \%$ \\
\hline \multirow[t]{2}{*}{8} & $\mathbf{0}$ & 1 & 2 & 7 \\
\hline & $0 \%$ & $10 \%$ & $20 \%$ & $70 \%$ \\
\hline \multirow[t]{2}{*}{9} & 1 & 6 & 2 & 1 \\
\hline & $10 \%$ & $60 \%$ & $20 \%$ & $10 \%$ \\
\hline \multirow[t]{2}{*}{10} & 3 & 5 & 1 & 1 \\
\hline & $30 \%$ & $50 \%$ & $10 \%$ & $10 \%$ \\
\hline
\end{tabular}

\subsubsection{Beban Kardiovaskular}

Beban Kardiovaskular atau Cardiovascular Load =\% CVL), adalah perbandingan antara peningkatan denyut nadi kerja dengan denyut nadi maksimum, yang dapat dihitung dengan rumus pada persamaan diklasifikasikan berat ringan beban kerja berdasarkan \% CVL: 
Contoh: menentukan beban kardiovaskular untuk pekerja 1

Denyut Nadi Maximal Pekerja = 220 - Umur. Pekerja 1 = 220 - 22 = 198 .

$$
\begin{aligned}
\% C V L & =\frac{(97 \text { denyut } / \mathrm{mnt}-66 \text { denyut } / \mathrm{mnt})}{(198 \text { denyut } / \mathrm{mnt}-66 \text { denyut } / \mathrm{mnt})} \times 100 \\
& =23,48 \%
\end{aligned}
$$

Klasifikasi $\% \mathrm{CVL}=$ Normal $(=<30 \%)$, tidak terjadi kelelahan $(>30 \%)$

\begin{tabular}{|c|c|c|c|c|c|c|c|}
\hline \multirow{2}{*}{ Pekerja } & $\begin{array}{c}\text { Denyut Nadi } \\
\text { Awal } \\
\end{array}$ & $\begin{array}{c}\text { Denyut Nadi } \\
\text { Kerja }\end{array}$ & NK & \multirow{2}{*}{$\begin{array}{l}\text { Umur } \\
\text { Tahun }\end{array}$} & DN Max & \multirow{2}{*}{$\begin{array}{c}\% \\
\text { CVL }\end{array}$} & \multirow{2}{*}{ Klasifikasi } \\
\hline & $\begin{array}{c}\text { Denyut/ } \\
\text { mnt }\end{array}$ & $\begin{array}{c}\text { Denyut/ } \\
\text { mnt }\end{array}$ & $\begin{array}{l}\text { DNK- } \\
\text { DNI }\end{array}$ & & $\begin{array}{c}\text { Denyut / } \\
\text { menit }\end{array}$ & & \\
\hline 1 & 66 & 97 & 31 & 22 & 198 & 23 & Normal \\
\hline 2 & 72 & 132 & 60 & 36 & 184 & 54 & \begin{tabular}{|l} 
Perlu \\
Perbaikan
\end{tabular} \\
\hline 3 & 72 & 130 & 58 & 38 & 182 & 53 & $\begin{array}{l}\text { Perlu } \\
\text { Perbaikan }\end{array}$ \\
\hline 4 & 78 & 110 & 32 & 36 & 184 & 30 & Normal \\
\hline 5 & 75 & 108 & 33 & 28 & 192 & 28 & Normal \\
\hline 6 & 74 & 115 & 41 & 28 & 192 & 35 & $\begin{array}{l}\text { Perlu } \\
\text { Perbaikan }\end{array}$ \\
\hline 7 & 78 & 100 & 22 & 29 & 191 & 19 & Normal \\
\hline 8 & 78 & 125 & 47 & 26 & 194 & 41 & $\begin{array}{l}\text { Perlu } \\
\text { Perbaikan }\end{array}$ \\
\hline 9 & 78 & 95 & 17 & 51 & 169 & 19 & Normal \\
\hline 10 & 75 & 131 & 56 & 21 & 199 & 45 & $\begin{array}{l}\text { Perlu } \\
\text { Perbaikan }\end{array}$ \\
\hline 11 & 61 & 108 & 47 & 49 & 171 & 43 & $\begin{array}{l}\text { Perlu } \\
\text { Perbaikan }\end{array}$ \\
\hline 12 & 69 & 126 & 57 & 27 & 193 & 46 & $\begin{array}{l}\text { Perlu } \\
\text { Perbaikan }\end{array}$ \\
\hline 13 & 72 & 130 & 58 & 46 & 174 & 57 & $\begin{array}{l}\text { Perlu } \\
\text { Perbaikan }\end{array}$ \\
\hline 14 & 66 & 98 & 32 & 21 & 199 & 24 & Normal \\
\hline 15 & 75 & 120 & 45 & 38 & 182 & 42 & $\begin{array}{l}\text { Perlu } \\
\text { Perbaikan }\end{array}$ \\
\hline
\end{tabular}

Tabel 4. Klasifikasi Berat Ringan Beban Kerja Berdasar \% CVL

Dari hasil Tabel 4. Klasifikasi Berat Ringan Beban Kerja Berdasar \% CVL bahwa yang mengalami terjadi kelelahan 9 pekerja, sedangkan 6 pekerja mengalami kelelahan, atau dengan persentasenya adalah:

Tabel 5. Persentase Beban Kerja Normal Dan Kelelahan 


\begin{tabular}{|c|l|c|c|}
\hline No & \multicolumn{1}{|c|}{ Klasifikasi \%CVL } & Jumlah & Persentase \\
\hline $\mathbf{1}$ & Normal, atau tidak kelelahan & 6 & $40 \%$ \\
\hline $\mathbf{2}$ & Perlu Perbaikan & 9 & $60 \%$ \\
\hline
\end{tabular}

\subsubsection{Beban Kerja}

Beban kerja pekerja pembuatan batu bata secara manual dapat diketahui dengan melihat dari hasil pengukuran berdasarkan Denyut Nadi awal (DNI) dan Denyut Nadi Kerja (DNK).

Tabel 6. Beban Kerja Pekerja Berdasarkan Kategori

\begin{tabular}{|c|c|l|c|l|}
\hline \multirow{3}{*}{ Pekerja } & Denyut Nadi Awal & \multirow{3}{*}{$\begin{array}{c}\text { Beban Kerja } \\
\text { DNI }\end{array}$} & $\begin{array}{c}\text { Denyut Nadi } \\
\text { Kerja }\end{array}$ & \multirow{2}{*}{$\begin{array}{c}\text { Beban Kerja } \\
\text { DNK }\end{array}$} \\
\cline { 2 - 3 } & $\begin{array}{c}\text { Denyut/ } \\
\text { mnt }\end{array}$ & & $\begin{array}{c}\text { Denyut/ } \\
\text { mnt }\end{array}$ & \\
\hline $\mathbf{1}$ & 66 & sangat ringan & 97 & ringan \\
\hline $\mathbf{2}$ & 72 & sangat ringan & 132 & berat \\
\hline $\mathbf{3}$ & 72 & sangat ringan & 130 & berat \\
\hline $\mathbf{4}$ & 78 & ringan & 110 & sedang \\
\hline $\mathbf{5}$ & 75 & sangat ringan & 108 & sedang \\
\hline $\mathbf{6}$ & 74 & sangat ringan & 115 & sedang \\
\hline $\mathbf{7}$ & 78 & ringan & 100 & ringan \\
\hline $\mathbf{8}$ & 78 & ringan & 125 & sedang \\
\hline $\mathbf{9}$ & 78 & ringan & 95 & ringan \\
\hline $\mathbf{1 0}$ & 75 & sangat ringan & 131 & berat \\
\hline $\mathbf{1 1}$ & 61 & sangat ringan & 108 & sedang \\
\hline $\mathbf{1 2}$ & 69 & sangat ringan & 126 & berat \\
\hline $\mathbf{1 3}$ & 72 & sangat ringan & 130 & berat \\
\hline $\mathbf{1 4}$ & 66 & sangat ringan & 98 & ringan \\
\hline $\mathbf{1 5}$ & 75 & sangat ringan & 120 & sedang \\
\hline
\end{tabular}

Dari hasil Tabel 6. Beban Kerja Pekerja Berdasarkan Kategori tersebut bahwa kategori pekerja persentasenya adalah:

Tabel 7. Persentase Beban Kerja Pekerja Berdasarkan Kategori

\begin{tabular}{|c|l|c|c|l|c|c|}
\hline & \multicolumn{3}{|c|}{ Sebelum Bekerja } & \multicolumn{2}{c|}{ Sesudah Bekerja } \\
\cline { 2 - 8 } No & $\begin{array}{c}\text { Kategori Beban } \\
\text { Kerja }\end{array}$ & Jumlah & Persentase & $\begin{array}{c}\text { Kategori } \\
\text { Beban Kerja }\end{array}$ & Jumlah & $\begin{array}{c}\text { Persen } \\
\text { tase }\end{array}$ \\
\hline $\mathbf{1}$ & Sangat ringan & 11 & $27 \%$ & Sangat ringan & 0 & 0 \\
\hline $\mathbf{2}$ & Ringan & 4 & $73 \%$ & Ringan & 4 & $27 \%$ \\
\hline 3 & Sedang & 0 & 0 & Sedang & 6 & $40 \%$ \\
\hline $\mathbf{4}$ & Berat & 0 & 0 & Berat & 5 & $33 \%$ \\
\hline
\end{tabular}

\subsubsection{Kelelahan Kerja}

Kelelahan kerja pada pekerja pembuatan batu bata secara manual dapat diketahui dengan melihat dari hasil total skor individu. Hasil pertanyaan dan diberi skor, misal Pekerja 1 dengan Skor pertanyaan adalah $=18+21+23=62$. Berdasarkan Tabel 2.4 pada Bab II maka nilai 62 berada pada Total Skor Individu antara $53-75$ adalah Klasifikasi Kelelahan = "Sedang".

Tabel 8. Total Skor Kelelahan Individu Dari Pertanyaan 15 Pekerja 


\begin{tabular}{|c|c|c|c|c|c|}
\hline \multirow{3}{*}{ Pekerja } & \multicolumn{4}{|c|}{ Total Skor Kelelahan Individu } & \multirow{3}{*}{$\begin{array}{l}\text { Kelelahan } \\
\text { Klasifikas }\end{array}$} \\
\hline & \multicolumn{3}{|c|}{ Instrumen Pertanyaan } & \multirow{2}{*}{$\begin{array}{l}\text { Skor } \\
\text { Total }\end{array}$} & \\
\hline & Instrumen 1 & Instrumen 2 & Instrumen 3 & & \\
\hline 1 & 18 & 21 & 23 & 62 & Sedang \\
\hline 2 & 16 & 21 & 21 & 58 & Sedang \\
\hline 3 & 20 & 29 & 21 & 70 & Sedang \\
\hline 4 & 21 & 22 & 25 & 68 & Sedang \\
\hline 5 & 15 & 17 & 20 & 52 & Rendah \\
\hline 6 & 15 & 18 & 21 & 54 & Sedang \\
\hline 7 & 14 & 28 & 15 & 57 & Sedang \\
\hline 8 & 16 & 17 & 24 & 57 & Sedang \\
\hline 9 & 23 & 24 & 27 & 74 & Sedang \\
\hline 10 & 18 & 23 & 17 & 58 & Sedang \\
\hline 11 & 12 & 32 & 25 & 69 & Sedang \\
\hline 12 & 14 & 21 & 21 & 56 & Sedang \\
\hline 13 & 23 & 29 & 28 & 80 & Tinggi \\
\hline 14 & 14 & 19 & 11 & 44 & Rendah \\
\hline 15 & 14 & 22 & 28 & 64 & Sedang \\
\hline
\end{tabular}

Berdasarkan Tabel 8 Total Skor Kelelahan Individu Dari Pertanyaan 15 Pekerja, rekapitulasi persentase yaitu sebagai berikut:

Tabel 9. Persentase Hasil Total Skor Kelelahan Individu

\begin{tabular}{|c|l|c|c|}
\hline No & Klasifikasi & Jumlah & Persentase \\
\hline $\mathbf{1}$ & Rendah & 2 & $13 \%$ \\
\hline $\mathbf{2}$ & Sedang & 12 & $80 \%$ \\
\hline $\mathbf{3}$ & Tinggi & 1 & $7 \%$ \\
\hline
\end{tabular}

\subsection{Pengolahan Data}

Tahap selanjutnya adalah melakukan pengolahan data, tahap ini melakukan pengujian terhadap hasil data lapangan dari angka denyut nadi, berat badan, tekanan darah, dan tinggi badan dengan Pelemahan Kegiatan dan Kelelahan Fisik. Metode pengujian yang dilakukan adalah Uji Normalitas, Uji Linearitas dan Uji Regresi Linier.

Tabel 10. Deskripsi Korelasi

\begin{tabular}{|c|c|c|c|c|c|c|c|}
\hline \multicolumn{8}{|c|}{ Posterior Distribution Characterization for Pairwise Correlations ${ }^{\mathrm{a}}$} \\
\hline & & & $\begin{array}{l}\text { Masa } \\
\text { Kerja }\end{array}$ & IMT & Umur & $\begin{array}{l}\text { Beban } \\
\text { Kerja }\end{array}$ & $\begin{array}{c}\text { Kelelahan } \\
\text { Kerja }\end{array}$ \\
\hline \multirow{6}{*}{$\begin{array}{l}\text { Masa } \\
\text { Kerja }\end{array}$} & \multirow[t]{3}{*}{ Posterior } & Mode & & .030 & .719 & -.261 & .466 \\
\hline & & Mean & & .024 & .646 & -.215 & .395 \\
\hline & & Variance & & .056 & .022 & .052 & .042 \\
\hline & \multirow{2}{*}{$\begin{array}{l}95 \% \\
\text { Credible } \\
\text { Interval }\end{array}$} & Lower Bound & & -.429 & .347 & -.643 & -.011 \\
\hline & & Upper Bound & & .478 & .896 & .228 & .766 \\
\hline & \multicolumn{2}{|l|}{$\mathrm{N}$} & 15 & 15 & 15 & 15 & 15 \\
\hline \multirow[t]{3}{*}{ IMT } & \multirow[t]{3}{*}{ Posterior } & Mode & .030 & & .307 & 300 & .514 \\
\hline & & Mean & .024 & & .255 & .249 & .440 \\
\hline & & Variance & .056 & & .050 & .050 & .039 \\
\hline
\end{tabular}




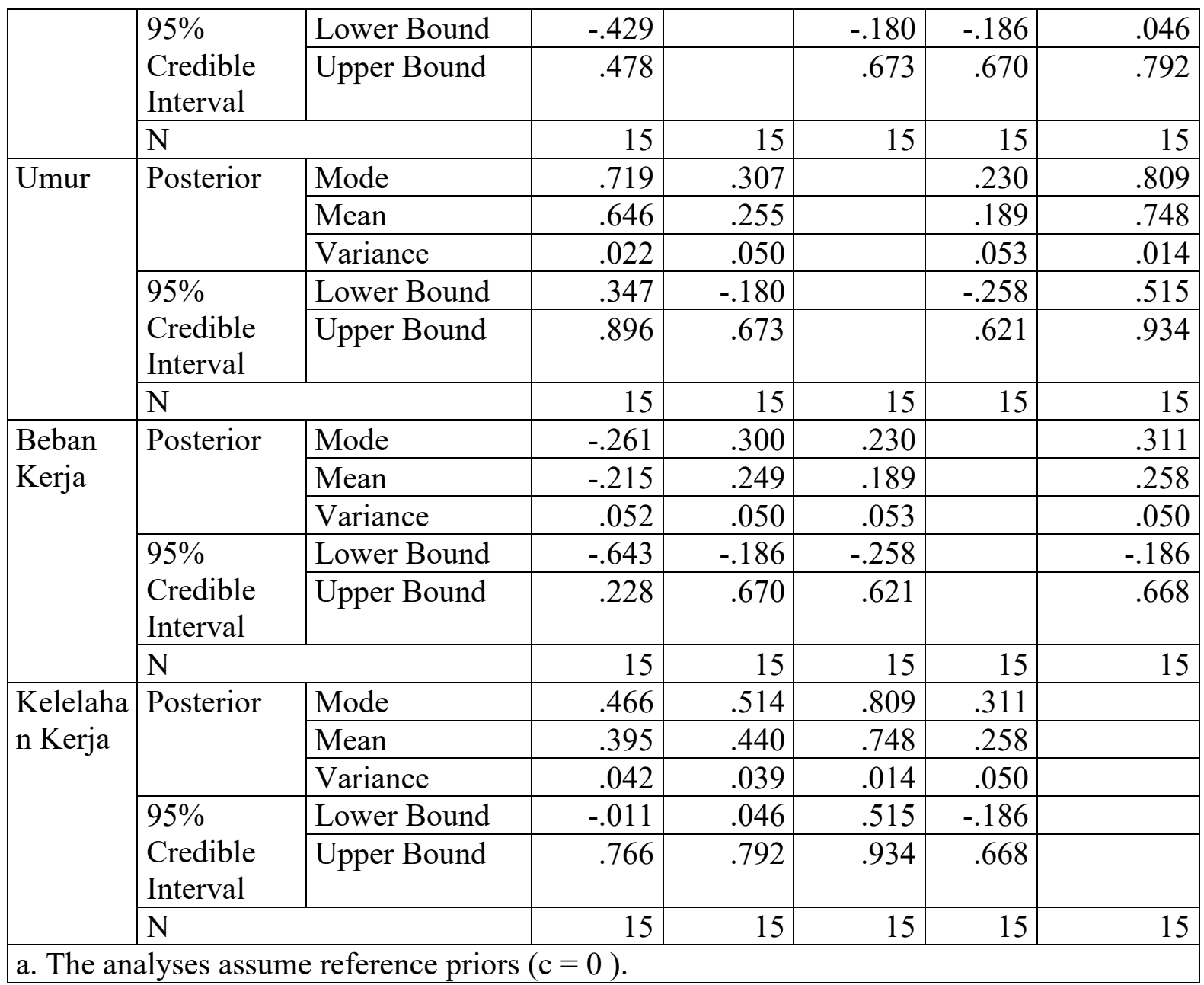

\subsubsection{Uji Normalitas}

Uji normalitas data dimaksudkan untuk memperlihatkan bahwa data sampel berasal dari populasi yang berdistribusi normal dengan Teknik One-Sample. Data dapat dikatakan berdistribusi normalal apabila nilai signifikan $>0,05$.

Tabel 11. Deskripsi Statistik

\begin{tabular}{|l|r|r|r|r|r|}
\hline \multicolumn{7}{|c|}{ Descriptive Statistics } \\
\hline & $\mathrm{N}$ & Minimum & Maximum & Mean & $\begin{array}{c}\text { Std. } \\
\text { Deviation }\end{array}$ \\
\hline Masa Kerja & 15 & 2 & 15 & 6.07 & 3.240 \\
\hline IMT & 15 & 18.1 & 21.5 & 19.07 & 1.0767 \\
& & & & 3 & \\
\hline Umur & 15 & 21 & 51 & 33.07 & 9.917 \\
\hline Beban Kerja & 15 & 19 & 57 & 37.27 & 12.853 \\
\hline Kelelahan Kerja & 15 & 44 & 80 & 61.53 & 9.349 \\
\hline Valid N (listwise) & 15 & & & & \\
\hline
\end{tabular}

Tabel 12. Distribusi Posterior 


\begin{tabular}{|c|c|c|c|c|c|c|}
\hline \multicolumn{7}{|c|}{ Posterior Distribution Characterization for One-Sample Mean } \\
\hline & \multirow[b]{2}{*}{$\mathrm{N}$} & \multicolumn{3}{|c|}{ Posterior } & \multicolumn{2}{|c|}{$95 \%$ Credible Interval } \\
\hline & & Mode & Mean & Variance & $\begin{array}{l}\text { Lower } \\
\text { Bound }\end{array}$ & $\begin{array}{l}\text { Upper } \\
\text { Bound }\end{array}$ \\
\hline Masa Kerja & 15 & 6.07 & 6.07 & .980 & 4.10 & 8.04 \\
\hline IMT & 15 & 19.073 & 19.073 & .108 & 18.419 & 19.728 \\
\hline Umur & 15 & 33.07 & 33.07 & 9.180 & 27.04 & 39.09 \\
\hline Beban Kerja & 15 & 37.27 & 37.27 & 15.420 & 29.46 & 45.08 \\
\hline Kelelahan Kerja & 15 & 61.53 & 61.53 & 8.158 & 55.85 & 67.21 \\
\hline
\end{tabular}

Tabel 13. Distribusi Normalitas

\begin{tabular}{|c|c|c|c|c|c|c|}
\hline \multicolumn{7}{|c|}{ Estimated Distribution Parameters } \\
\hline & & Masa Kerja & IMT & Umur & $\begin{array}{l}\text { Beban } \\
\text { Kerja }\end{array}$ & $\begin{array}{l}\text { Kelelahan } \\
\text { Kerja }\end{array}$ \\
\hline \multirow[t]{2}{*}{$\begin{array}{l}\text { Normal } \\
\text { Distribution }\end{array}$} & $\begin{array}{l}\text { Loca- } \\
\text { tion }\end{array}$ & 6.067 & 19.073 & 33.067 & 37.267 & 61.533 \\
\hline & Scale & 3.2396 & 1.0767 & 9.9173 & 12.8534 & 9.3493 \\
\hline
\end{tabular}

\subsubsection{Uji Linearitas}

Uji regresi linear dilakukan dengan derajat kepercayaan yang digunakan adalah 0,05 , apabila nilai signifikansi lebih besar dari 0,05 , maka terdapat hubungan linear secara signifikan antara variabel independen $(\mathrm{X})$ dengan variabel dependen $(\mathrm{Y})$. sebaliknya jika nilai signifikansi lebih kecil dari 0,05 , maka tidak terdapat hubungan linear secara signifikan antara variabel independen $(\mathrm{X})$ dengan variabel dependen $(\mathrm{Y})$.

Table 14. Hasil Uji Linearitas Beban Kerja Dengan Kelelahan Kerja

\begin{tabular}{|l|r|r|r|r|c|}
\hline \multicolumn{7}{|c|}{ ANOVA } \\
\hline Kelelahan Kerja & $\begin{array}{c}\text { Sum of } \\
\text { Squares }\end{array}$ & \multicolumn{1}{|c|}{ df } & $\begin{array}{c}\text { Mean } \\
\text { Square }\end{array}$ & F & Sig. \\
\hline Between Groups & 1079.233 & 13 & 83.018 & .575 & .790 \\
\hline Within Groups & 144.500 & 1 & 144.500 & & \\
\hline Total & 1223.733 & 14 & & & \\
\hline
\end{tabular}

Table 15. Uji Regresi Linier Berganda - Uji F

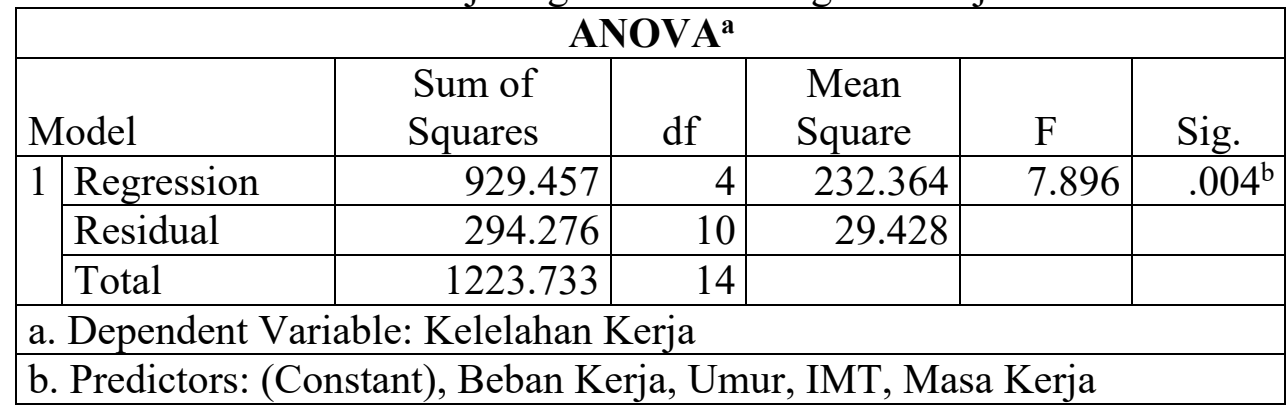

Table 16. Uji Regresi Linier Berganda - Koefisien 


\begin{tabular}{|c|c|c|c|c|c|}
\hline \multicolumn{6}{|c|}{ Coefficients $^{\mathrm{a}}$} \\
\hline \multirow[t]{2}{*}{ Model } & \multicolumn{2}{|c|}{$\begin{array}{l}\text { Unstandardized } \\
\text { Coefficients }\end{array}$} & $\begin{array}{l}\text { Standardized } \\
\text { Coefficients }\end{array}$ & $\mathrm{t}$ & Sig. \\
\hline & B & Std. Error & Beta & & \\
\hline 1 (Constant) & -6.266 & 26.935 & & -.233 & .821 \\
\hline Masa Kerja & -.407 & .902 & -.141 & -.452 & .661 \\
\hline IMT & 2.314 & 1.497 & .267 & 1.546 & .153 \\
\hline Umur & .790 & .300 & .838 & 2.630 & .025 \\
\hline Beban Kerja & .000 & .157 & .000 & .001 & .999 \\
\hline
\end{tabular}

\section{Hasil Dan Pembahasan}

\subsection{Beban Kardiovaskular $($ Cardiovascular $=\%$ CVL $)$}

Berdasarkan dari pengolahan data bahwa responden yang mengalami tidak terjadi kelelahan / normal 6 pekerja dengan persentase sebesar $40 \%$, sedangkan yang mengalami diperlukan perbaikan 9 pekerja dengan persentase sebesar $60 \%$.

\subsection{Beban Kerja}

Berdasarkan dari hasil analisis data beban kerja pada pekerja pembuatan batu bata secara manual di Desa Mario - Batuah. Untuk sebelum bekerja pekerja yang mengalami beban kerja sangat ringan adalah sebanyak 11 pekerja dengan persentase sebesar $73 \%$, pekerja yang mengalami beban kerja ringan sebanyak 4 pekerja dengan persentase sebesar $27 \%$.

Beban kerja setelah bekerja yang mengalami beban kerja ringan adalah:

a. sebanyak 4 pekerja dengan persentase sebesar $27 \%$,

b. pekerja yang mengalami beban kerja sedang sebanyak 6 pekerja dengan persentase sebesar $40 \%$, dan

c. untuk pekerja yang mengalami beban kerja berat sebanyak 5 pekerja dengan persentase sebesar 33\%.

Berat ringannya beban kerja sangat dipengaruhi oleh jenis aktivitas (sebagai beban utama) dan lingkungan kerja (sebagai beban tambahan). Peningkatan denyut nadi dan umur mempunyai peran sangat penting dalam peningkatan cardic output dari istirahat sampai kerja maksimum (Tarwaka, 2010).

\subsection{Kelelahan Kerja}

Berdasarkan dari hasil analisis data total skor kelelahan individu, responden yang mengalami:

a. kelelahan kerja normal atau rendah sebanyak 2 pekerja dengan persentase sebesar $13 \%$,

b. pekerja yang mengalami kelelahan kerja ringan sebanyak 12 pekerja dengan persentase sebesar $80 \%$, dan

c. pekerja yang mengalami kelelahan kerja sedang sebanyak 1 pekerja dengan persentase sebesar $7 \%$.

Tenaga kerja mampu melaksanakan tugasnya dengan mudah dengan beban kerja dan performansi tetap pada tingkat optimal, jika terjadi peningkatan beban kerja berupa peningkatan tuntutan tugas yang besar maka hal tersebut akan menyebabkan beban kerja kognitif sehingga dapat menyebabkan kelelahan pada pekerja (Tarwaka, 2010).

\section{Kesimpulan}

Berdasarkan Hasil dan Pembahasan sebelumnya, maka dapat disimpulkan bahwa berdasarkan Tabel 14, 15, dan 16 memiliki nilai signifikansi sebesar 0,575 lebih besar dari 
0,05, maka terdapat hubungan linear secara signifikan antara variabel beban kerja dengan variabel kelelahan kerja.

Berdasarkan nilai F: dari output diatas, diperoleh nilai $\mathrm{F}_{\text {hitung }}=0,922$ lebih kecil dari $\mathrm{F}_{\text {tabel, }}$ maka dapat disimpulkan bahwa terdapat hubungan linear secara signifikan antara variabel beban kerja dengan variabel kelelahan kerja.

\section{Referensi}

[1] Hidayah, N., Musyarofah, St., dan Widjasena, B. 2018. Analisis Beban Kerja Terhadap Kelelahan Kerja Antara Shift Pagi Dan Shift Siang Pada Pekerja Di Bagian Operasional. Jurnal Ilmiah Permas, STIKES Kendal Vol.8 No.2, Hal.107-115.

[2] Juliana M., Camelia A., dan Rahmiwati A., 2018. Analisis Faktor Risiko Kelelahan Kerja Pada Karyawan Bagian Produksi PT. Arwana Anugrah Keramik, Tbk. Jurnal Ilmu Kesehatan Masyarakat Vol.9 No.1, Hal 53-63.

[3] Nurmianto, E., 2003. Ergonomi Konsep Dasar dan Aplikasinya. Guna Widya, Surabaya.

[4] Suma'mur, P. K., 2009. Higiene Perusahaan dan Kesehatan Kerja (HIPERKES). Sagung Seto, Jakarta.

[5] Sunarso. (2010). Pengaruh kepemimpinan, kedisplinan,Beban Kerja dan Motivasi Kerja terhadap Kinerja Guru Sekolah.Jurnal Managemen Sumber Daya Manusia. Vol 4. No 1.

[]Tarwaka, 2010. Dasar-Dasar Pengetahuan Ergonomi dan Aplikasi Di Tempat Kerja. Harapan Press Solo, Solo.

[7] World Health Organization (WHO), 2003. Globals Goals for Oral Health 2020.

\section{Profil Penulis:}

Junaini, Kelahiran Murung Pudak, Kalimantan Selatan, 27
September 1970. Penulis merupakan staf pengajar Sekolah
Tinggi Teknologi Industri Bontang dengan bidang keahlian
Teknik Informatika. Penelitian penulis lebih fokus pada
bidang Teknik Mesin sesuai home base yaitu Informatika
dan Energi. Email: jhunaini99@yahoo.co.id.

